\title{
Gender Analysis of Academic Achievement among the High School Students of Urban Srinagar and Rural Bandipora Districts
}

\author{
Tariq Ahmad Guroo \\ Political Science Research Scholar \\ Barkatullah University, India
}

\begin{abstract}
Education is the processes of developing the capacities and potentials of the individual so as to prepare that individual to be successful in his/her society. A lot of time and effort of the schools are used for helping students to achieve better in their scholastic activities. The importance of scholastic and academic achievement has raised important questions for educational researcher. What factors promote achievement in students? How far do the different factors contribute towards academic achievement?
\end{abstract}

KEYWORDS: Gender Analysis, Academic Achievement, High School Students, Urban Srinagar and Rural Bandipora Districts.

\section{Introduction:}

Education is the processes of developing the capacities and potentials of the individual so as to prepare that individual to be successful in his/her society. A lot of time and effort of the schools are used for helping students to achieve better in their scholastic activities. The importance of scholastic and academic achievement has raised important questions for educational researcher. What factors promote achievement in students? How far do the different factors contribute towards academic achievement?

There are several factors which influence the academic achievement of student like study habits, self-concept and socio-economic status which researcher go to study how these factors academic achievements of the students.

Operational Definitions:

$\checkmark$ Study Habits; it is a planned programme of subject matter mastery. It refers to the activities carried out by learners during the learning process of improving learning. 
$\checkmark$ Self -concept; as a child grows and develops, he learns not only about himself and his place and relationship with others. A person's self-concept is the fundamental core of his/her entire personality and determines the quality of behaviour. It can be predicted that the poor self-concept implying lack of confidence, in facing and mastering the environment will accomplish his performance in school in sum; the self-concept does appear to be related to school adjustment.

$\checkmark$ Socio-economic; socio-economic status plays an important role in the life of a person. The status opens the ways for his progress, intelligences, attitude, aptitudes and even interests are patterns by socioeconomic background of the individual. The socio-economic status plays rewards and punishment both to be a person. Socio-economic refers to the position that an individual and family occupies with reference to prevailing average standards.

$\checkmark$ Gender;- now the gender discrimination are not so marked in today's world, thus the present study is an attempt to find out the gender difference if any, on the factor affecting academic achievements.

$\checkmark$ Locale; the educators and the general public believe that students from rural or smaller area receive an education that is inferior to that of students from metropolitan or urban schools. Until recently, there has been little empirical evidence to the challenges this view point. Thus the present study is an attempt to find out the difference between the rural and urban students if any have, on the factors affecting academic achievements.

$\checkmark$ Academic achievements; (Crow \& Crow) "academic achievement as the extent to which a leaner is profiting from instructions in a given area of learning i.e. achievement is reflected by the extent to which skill or knowledge has been imparted to him." Academic achievements have become an index of child's future in this highly competitive world. Academic achievement has been one of the most important goals of the educational processes.

\section{Objectives:}

1. To analysis the study habits of boys and girls studying in $8^{\text {th }} 9^{\text {th }}$ and $10^{\text {th }}$ standards.

2. To study the self-concept of boys and girls in $8^{\text {th }} 9^{\text {th }}$ and $10^{\text {th }}$ standards.

3. To know the influence of study habits, self-concept and socio-economic on academic achievements.

4. To compare the rural urban students on study habits, self-concept economic status and academic achievements.

\section{Hypothesis:}

1. There is significant association between study habits of girls and academic achievements

2. Thereis significant relation between study habits and academic achievements.

3. There is significant association between self-concept and academic achievements among the boys and girls.

4. There is significant association between socio-economic status and academic achievements among the boys and girls.

5. There is significant association between socio-economic status and academic achievements between the rural/urban students.

6. There is significant association between academic achievements with boys and girls.

\section{Methodology:}

A study on "Gender analysis of academic achievements among high school students" was carried out in Srinagar city and rural Bandipora district of Kashmir valley. The material and method used for data collection are as below:

Universe: Two districts were selected for the present study namely district Srinagar and district Bandipora in the Kashmir valley.

Sample: the sample for the study was 600 students. Out of all 300 were drawn from Urban Srinagar city/district and 300 were from rural Bandipora district. Two schools were selected randomly from each district. Furthermore each school 150 students, with 50 students in each class i.e. $8^{\text {th }}, 9^{\text {th }}$ and 10 th were randomly selected. Out of total sample there were 325 boys and 275 girl students. The study was conducted in two English medium schools from each district. The distribution of student's class, sex and locale wise are present in tabular wise below; 
Table 1

Profile of respondents

\begin{tabular}{|c|c|c|c|c|c|c|}
\hline \multirow[b]{2}{*}{ locale } & \multicolumn{3}{|l|}{ Urban } & \multicolumn{3}{|l|}{ Rural } \\
\hline & Class $8^{\text {th }}$ & Class $9^{\text {th }}$ & $\begin{array}{l}\text { Class } \\
10^{\text {th }}\end{array}$ & Class $8^{\text {th }}$ & Class $9^{\text {th }}$ & $\begin{array}{l}\text { Class } \\
10^{\text {th }} \\
\end{array}$ \\
\hline Boys & 57 & 67 & 52 & 49 & 50 & 50 \\
\hline Girls & 43 & 33 & 48 & 51 & 50 & 50 \\
\hline Total & 100 & 100 & 100 & 100 & 100 & 100 \\
\hline
\end{tabular}

Table 2

Demographic profile of respondents:

\begin{tabular}{|c|c|c|c|c|c|c|c|}
\hline \multirow[b]{2}{*}{ Characteristics } & \multirow[t]{2}{*}{ Category } & \multicolumn{2}{|c|}{ Boys $(\mathrm{N}=325)$} & \multicolumn{2}{|c|}{ Girls $(N=275)$} & \multicolumn{2}{|c|}{ Total $(\mathrm{N}=600)$} \\
\hline & & $\mathrm{N}$ & $\%$ & $\mathrm{~N}$ & $\%$ & $\mathrm{~N}$ & $\%$ \\
\hline \multirow[b]{3}{*}{ Age } & 13 & 99 & 30.5 & 101 & 36.7 & 200 & 33.33 \\
\hline & 14 & 114 & 35.1 & 86 & 31.3 & 200 & 33.33 \\
\hline & 15 & 112 & 34.5 & 88 & 32 & 200 & 33.33 \\
\hline \multirow[b]{3}{*}{ Class } & 8th & 106 & 32.6 & 94 & 34.2 & 200 & 33.33 \\
\hline & 9th & 117 & 36 & 83 & 30.2 & 200 & 33.33 \\
\hline & 10th & 102 & 31.4 & 98 & 35.6 & 200 & 33.33 \\
\hline \multirow[b]{3}{*}{ Ordinal position } & First born & 126 & 38.8 & 129 & 46.9 & 255 & 42.5 \\
\hline & Second born & 122 & 37.5 & 85 & 30.9 & 207 & 34.5 \\
\hline & Third born & 77 & 23.7 & 61 & 22.2 & 138 & 23 \\
\hline \multirow[b]{2}{*}{ Area } & Rural & 149 & 45.8 & 151 & 54.9 & 300 & 50 \\
\hline & Urban & 176 & 54.2 & 124 & 45.1 & 300 & 50 \\
\hline \multirow[b]{2}{*}{ Type of family } & Nuclear & 245 & 75.4 & 206 & 74.9 & 451 & 75.2 \\
\hline & Joint & 80 & 24.6 & 69 & 25.1 & 149 & 24.8 \\
\hline \multirow[b]{3}{*}{ Family size } & 1-4 small & 164 & 50.5 & 131 & 47.6 & 295 & 49.2 \\
\hline & 5-8 medium & 131 & 40.3 & 106 & 38.5 & 237 & 39.5 \\
\hline & $>9$ large & 30 & 9.2 & 38 & 13.8 & 68 & 11.3 \\
\hline
\end{tabular}

Table 3

Demographic characteristics of families of respondents:

\begin{tabular}{|c|c|c|c|c|c|c|c|}
\hline \multirow[b]{2}{*}{ Characteristics } & \multirow[t]{2}{*}{ Category } & \multicolumn{2}{|c|}{ Boys $(\mathrm{N}=325)$} & \multicolumn{2}{|c|}{ Girls $(N=275)$} & \multicolumn{2}{|c|}{ Total $(\mathrm{N}=600)$} \\
\hline & & $\mathrm{N}$ & $\%$ & $\mathrm{~N}$ & $\%$ & $\mathrm{~N}$ & $\%$ \\
\hline \multirow[b]{6}{*}{ Father's education } & Illiterate & 45 & 13.8 & 41 & 14.9 & 86 & 14.3 \\
\hline & Primary & 66 & 20.3 & 60 & 21.8 & 126 & 21 \\
\hline & High School & 35 & 10.8 & 41 & 14.9 & 76 & 12.7 \\
\hline & 12 th & 39 & 12 & 30 & 10.9 & 69 & 11.5 \\
\hline & college & 82 & 25.2 & 64 & 23.3 & 146 & 24.3 \\
\hline & P.G & 58 & 17.8 & 39 & 14.2 & 97 & 16.2 \\
\hline \multirow[b]{6}{*}{ Mother's edu. } & Illiterate & 71 & 21.8 & 67 & 24.4 & 138 & 23 \\
\hline & Primary & 70 & 21.5 & 60 & 21.8 & 130 & 21.7 \\
\hline & High School & 56 & 17.2 & 45 & 16.4 & 101 & 16.8 \\
\hline & 12th & 44 & 13.5 & 33 & 12 & 77 & 12.8 \\
\hline & college & 66 & 20.3 & 50 & 18.2 & 116 & 19.3 \\
\hline & P.G & 18 & 5.5 & 20 & 7.3 & 39 & 6.3 \\
\hline \multirow[b]{6}{*}{ Occupation of father } & Unemployment & 8 & 2.5 & 1 & 0.4 & 1 & 0.2 \\
\hline & Labourer & 64 & 19.7 & 62 & 22.5 & 1236 & 21 \\
\hline & caste Occupation & 12 & 3.7 & 8 & 2.9 & 20 & 3.3 \\
\hline & Small Bussiness & 74 & 22.8 & 88 & 32 & 162 & 27 \\
\hline & Bussiness & 86 & 26.5 & 65 & 23.6 & 151 & 25.2 \\
\hline & Professional & 81 & 24.9 & 50 & 18.2 & 131 & 21.8 \\
\hline \multirow[b]{4}{*}{ Occupation of Mother's } & House wife & 217 & 66.8 & 161 & 59.5 & 378 & 63 \\
\hline & Labourer & 66 & 20.3 & 69 & 24.7 & 134 & 22.3 \\
\hline & caste Occupation & 2 & 0.6 & 1 & 0.4 & 3 & 0.5 \\
\hline & Government job & 40 & 12.3 & 45 & 16.4 & 85 & 14.2 \\
\hline \multirow[b]{3}{*}{ Father's Income } & Low & 169 & 52 & 156 & 56.7 & 325 & 54.2 \\
\hline & Medium & 86 & 26.5 & 78 & 28.4 & 164 & 27.3 \\
\hline & High & 63 & 19.4 & 36 & 13.1 & 99 & 16.5 \\
\hline \multirow[b]{3}{*}{ Mother's Income } & Low & 76 & 23.4 & 78 & 28.4 & 154 & 25.7 \\
\hline & Medium & 23 & 7.1 & 24 & 8.7 & 47 & 7.8 \\
\hline & High & 14 & 1.3 & 12 & 4.4 & 26 & 4.3 \\
\hline
\end{tabular}


Research Design: The adaptability of the proposed research design with respect to the type of study, variables under consideration, size of sample and phenomena to be studied, the ex-post facto design was selected as an appropriate research design.

\section{Tools used for data collection:}

1. Self-concept scale developed by Singh and Singh

2. Study habit inventory developed by Patel

3. Socio-economic status scale developed by AICRP-CD.

\section{Variables:}

Independent variables;

$\checkmark$ Study habits,

$\checkmark$ Self-Concept,

$\checkmark$ Socio-economic status.

Dependent variables;
$\checkmark$ Academic achievement
$\checkmark$ Age
$\checkmark$ Locale
$\checkmark$ Gender
$\checkmark \quad$ Size of family
$\checkmark \quad$ Education of parents

\section{Discussion:}

Table 4

Distribution boy's and girl's on study habits

\begin{tabular}{|c|c|c|c|c|c|}
\hline & Boys & & Girls & & $x^{2}$ \\
\hline Stdu Habits & $\mathrm{F}$ & $\%$ & $\mathrm{~F}$ & $\%$ & sig \\
\hline Poor & 126 & 38.8 & 106 & 38.5 & \\
\hline Average & 153 & 47.1 & 134 & 48.7 & \\
\hline Good & 46 & 14.2 & 35 & 12.7 & \\
\hline Total & 325 & 100 & 275 & 100 & 0.31 \\
\hline
\end{tabular}

The above tabled shows that $14.20 \%$ of boys and $12.7 \%$ of girls had good study habits, while as, $47.10 \%$ of boys and $48.70 \%$ of girls had average study habits, whereas, $38.80 \%$ of boys and $38.50 \%$ of girls had poor study habits. The association between boys and girls on study habits found to be non-significant $\left(\mathrm{x}^{2}=0.31\right)$.

Table 5

Class wise comparison of the study habits:

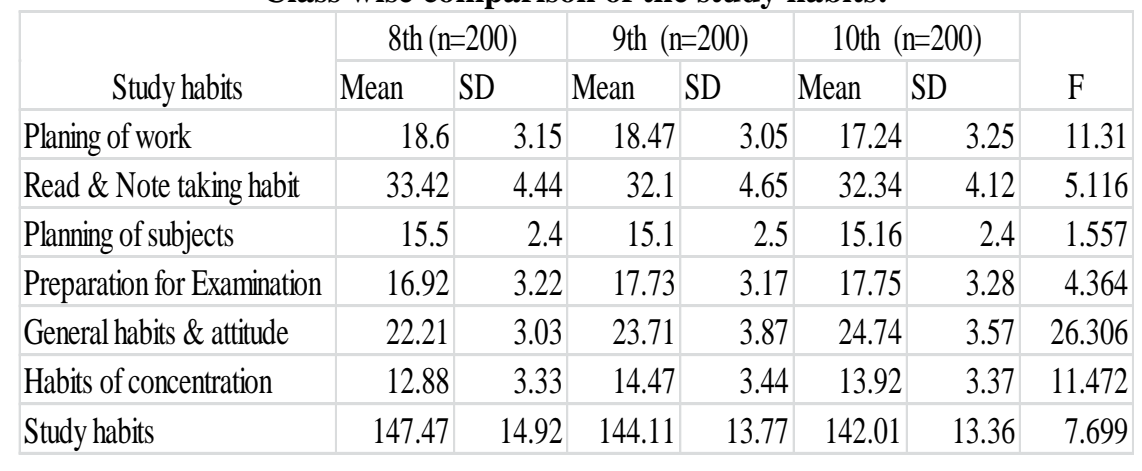

The class wise comparison of study habits is tabled above. It was observed that all the three class had differed significantly on overall study habits as the F-value 7.699 was significant at 5 per cent of probability. It was noted that $8^{\text {th }}$ class students had significant better study habits as compared to $9^{\text {th }}$ and $10^{\text {th }}$ class students. The score are 147.47, 144.11 and 142.01 respectively. 
Table 6

\begin{tabular}{|c|c|c|c|c|c|}
\hline \multicolumn{6}{|c|}{ Association of study habits of boys and girls with academic achievements: } \\
\hline Academic achi & lent & Poor & Average & Good & Frequency \\
\hline \multirow[b]{2}{*}{ Excellent } & Boys & $68(34.9)$ & $97(49.7)$ & $30(15.4)$ & 195 \\
\hline & Girls & $47(32.2)$ & $73(50.0)$ & 26(17.8) & 146 \\
\hline \multirow[b]{2}{*}{ Good } & Boys & 43(43.9) & $41(41.9)$ & $14(14.3)$ & 99 \\
\hline & Girls & $39(41.1)$ & $52(54.7)$ & $4(4.2)$ & 95 \\
\hline \multirow[b]{2}{*}{ Satisfactors } & Boys & $8(38.1)$ & $12(57.1)$ & $1(4.8)$ & 21 \\
\hline & Girls & $19(59.4)$ & $9(28.1)$ & $4(12.5)$ & 32 \\
\hline \multirow[b]{2}{*}{ Poor } & Boys & $7(63.3)$ & $3(27.3)$ & $1(9.1)$ & 11 \\
\hline & Girls & $1(50.0)$ & & $1(50.0)$ & 2 \\
\hline \multirow[b]{2}{*}{ Total } & Boys & \multicolumn{3}{|c|}{$126(38.8153(47.1) 46(14.2)$} & 325 \\
\hline & Girls & \multicolumn{3}{|c|}{$106(38.5134(48.7) 35(12.7)$} & 275 \\
\hline \multirow[b]{2}{*}{ Chi-square } & Boys & \multicolumn{4}{|c|}{$7.13 *$} \\
\hline & Girls & \multicolumn{4}{|c|}{$20.43 * *$} \\
\hline
\end{tabular}

The above tabled data showed that there was no significant association between study habits and academic achievements among the boys while as, there was found a significant association between study habits and academic achievements among the girls.

Table 7

Distribution of boys and girls on self-concept:

\begin{tabular}{|c|c|c|c|c|c|}
\hline \multirow[b]{3}{*}{ Self-concept } & 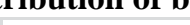 & 0 & 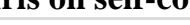 & 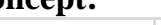 & \\
\hline & \multicolumn{2}{|c|}{ Boys } & \multicolumn{2}{|c|}{ Girls } & \multirow{2}{*}{$x^{2}$} \\
\hline & Frequency & $\%$ & Frequency & $\%$ & \\
\hline Low & 30 & 9.2 & 21 & 32.7 & \\
\hline Medium & 96 & 29.5 & 85 & 29.5 & \\
\hline High & 199 & 61.2 & 169 & 37.8 & \\
\hline Total & 325 & 100 & 275 & 275 & $0.54^{*}$ \\
\hline
\end{tabular}

$* \mathrm{p}<0.05$ level,

The above table revolves round that 61.2 per cent of boys and 37.8 per cent of girls had developed high selfconcept, which had also high in frequency and in per cent among both boys and girls, while as 29.5 per cent of boys and girls both had developed medium self-concept. Low self-concept was found in 9.2 per cent of boys and 32.7 per cent of girls. The association of gender on self-concept was significant at 5 per cent of level. It may be due to difference in thinking, decision making, and relations with parents, teachers and friends might have contributed to difference in self-concept.

Table 7

Class wise comparison of the self-concept:

\begin{tabular}{|c|c|c|c|c|c|c|c|c|c|}
\hline \multicolumn{10}{|c|}{ self-concept } \\
\hline \multicolumn{2}{|c|}{ 8th } & \multicolumn{2}{|c|}{ 9th } & \multicolumn{3}{|c|}{ 10th } & \multicolumn{2}{|c|}{ Total } & F-Vale \\
\hline Mean & SD & Mean & SD & & Mean & SD & Mean & SD & \\
\hline 91.43 & 8.61 & 89.96 & & 8 & 88.63 & 7.33 & 90 & 8.06 & 6.16 \\
\hline
\end{tabular}

The analysis from the above table that all the three groups differed significant on the self-concept as the F-vale of 6.16 was found to be significant at 1 per cent level of probability. The table also shows that all the three classes (i.e. $8^{\text {th }}, 9^{\text {th }}$ and $10^{\text {th }}$ ) different differed significantly on self-concept; it has been found that $8^{\text {th }}$ standard students displayed higher level of self-concept than $9^{\text {th }}$ and $10^{\text {th }}$ standard students. The mean score were 91.43 , 89.96 and 88.63 while SD scores were $8.61,8$, and 7.33 among the three groups $8^{\text {th }}, 9^{\text {th }}$ and $10^{\text {th }}$ respectively. The self-concept of students develops under the continuous influence of the teacher, school, family, friends and social-environment. These factors may affect the development of self-concept in later stage because of examination tension. 
Table 8

Association of self-concept of boys and girls with academic achievements:

\begin{tabular}{|c|c|c|c|c|c|}
\hline \\
\hline Academic achiv & nent & Poor & Average & Good & Frequency \\
\hline \multirow[b]{2}{*}{ Excellent } & Boys & $12(40)$ & $50(52.1)$ & $133(66.8)$ & 195 \\
\hline & Girls & $42(42.9)$ & $32(37.6)$ & $105(62.1)$ & 146 \\
\hline \multirow[b]{2}{*}{ Good } & Boys & $10(33.3)$ & $38(39.6)$ & $50(25.11)$ & 98 \\
\hline & Girls & $5(23.8)$ & $36(42.4)$ & $54(32.0)$ & 95 \\
\hline \multirow[b]{2}{*}{ Satisfactors } & Boys & $5(16.7)$ & $6(6.3)$ & $10(5.0)$ & 21 \\
\hline & Girls & $7(33.3)$ & $17(20.0)$ & $9(4.70)$ & 32 \\
\hline \multirow[b]{2}{*}{ Poor } & Boys & $3(10.0)$ & $2(2.1)$ & $6(3.0)$ & 11 \\
\hline & Girls & & & $2(1.2)$ & 2 \\
\hline \multirow[b]{2}{*}{ Total } & Boys & $30(100.0)$ & $96(100.0)$ & 199(100.0) & 325 \\
\hline & Girls & 21(100.0) & $85(100.0)$ & 169100.0) & 275 \\
\hline \multirow[b]{2}{*}{ Chi-square } & Boys & \multicolumn{4}{|c|}{$19.07 * *$} \\
\hline & Girls & \multicolumn{4}{|c|}{$31.14 * *$} \\
\hline
\end{tabular}

The 199 boys and 169 girls had good self-concept, while as 96 boys and 85 girls had average self-concept, and 30 boys and 21 girls had poor self-concept out of 325 and 275 boys and girls respectively.

The association of self-concept of boys and girls with academic achievement was significant (19.07 and 31.14 $\mathrm{p}<0.01$ level respectively). The students with high self-concept are confident about their abilities, to accomplish their goals, have possesses high academic competence, have a clear sense of self and are independent. These qualities might have influenced the boys and girls have influenced the boys and girls to attain better academic performance.

Table 9

Association of socio-economic status of boys and girls with academic achievements

\begin{tabular}{|c|c|c|c|c|c|c|}
\hline Socio-econonic status & \multicolumn{2}{|c|}{ Academic achivement Poor } & \multirow{2}{*}{$\begin{array}{l}\text { Average } \\
110(67.9)\end{array}$} & \multirow{2}{*}{$\begin{array}{l}\text { Good } \\
14(77.8)\end{array}$} & \multirow{2}{*}{$\begin{array}{r}\text { Frequency } \\
195\end{array}$} & \multirow{2}{*}{ Total boys \& girls } \\
\hline & Boys & $71(49.0)$ & & & & \\
\hline Excellent & Girls & $57(43.5)$ & $89(59.5)$ & $20(71.4)$ & 146 & 314 \\
\hline \multirow[b]{2}{*}{ Good } & Boys & $54(37.2)$ & $41(25.3)$ & $3(16.7)$ & 98 & \multirow[b]{2}{*}{193} \\
\hline & Girls & $64(48.9)$ & $28(24.1)$ & $3(10.7)$ & 95 & \\
\hline \multirow[b]{2}{*}{ Satisfactors } & Boys & $12(8.3)$ & $8(4.8)$ & $1(5.6)$ & 21 & \multirow[b]{2}{*}{53} \\
\hline & Girls & $8(6.1)$ & $19(16.4)$ & $5(17.9)$ & 32 & \\
\hline \multirow[b]{2}{*}{ Poor } & Boys & $8(5.5)$ & $3(1.9)$ & & 11 & \multirow[b]{2}{*}{13} \\
\hline & Girls & $2(1.5)$ & & & 2 & \\
\hline \multirow[b]{2}{*}{ Total } & Boys & 145 & 162 & 18 & 325 & \multirow[b]{2}{*}{600} \\
\hline & Girls & 131 & 116 & 28 & 275 & \\
\hline & Boys & \multicolumn{5}{|c|}{$29.75^{* *}$} \\
\hline Chi-square & Girls & \multicolumn{5}{|c|}{$15.36^{*}$} \\
\hline
\end{tabular}

The above table revealed that was significant association between socio-economic status and academic achievement among the boys and girls at 1 per cent level. This can be explained that good socio-economic status is a facilitating factor of academic achievement. The scores were 77.80 per cent of boys and 71.40 per cent of girls with good socio-economic status and 67.90per cent of boys and 59.50 per cent of girl with average socioeconomic status while as, 49.00 per cent of boys and 43.50 per cent of girls with low/ poor socio-economic status. The association level of socio-economic status and academic achievements of boys and girls had significant association (29.75 and 15.36 at $\mathrm{p}<0.01$ level and $\mathrm{p}<0.05$ level respectively). 
Table 10

Distribution of rural urban students on study habits:

Note: p, 0.01level.

\begin{tabular}{|l|r|r|r|r|r|}
\hline & \multicolumn{3}{|c|}{ Rural } & \multicolumn{3}{c|}{ Urban } & $x^{2}$ \\
\cline { 2 - 6 } \multicolumn{1}{r|}{ Study Habits } & F & $\%$ & F & $\%$ & $\mathrm{n}=600$ \\
\hline Poor & 88 & 29.3 & 144 & 48 & \\
\hline Average & 162 & 54 & 125 & 41.7 & \\
\hline Good & 50 & 16.7 & 31 & 10 & \\
\hline Total & 300 & 100 & 300 & 100 & $22.74 * *$ \\
\hline
\end{tabular}

The above table shows that 16.70 per cent of rural students and 10.00 per cent of urban students had good study habits. There number was 50 and 31 students out of 600 students respectively. 54.00 per cent and 41.70 per cent of students had average study habits while as 29.30 per cent and 48.00 per cent had poor study habits among the 300 boys and 300 girls respectively.

The above table also showed that association between study habits with rural/urban students was significant at 1 per cent level. Rural students were having better study habits compared to urban students. The association was found to be significant on the level of study habits and rural/urban students $(22.74, \mathrm{p}<0.01$ level).

Table 11

Distribution of rural/urban students on self-concept:

\begin{tabular}{|c|c|c|c|c|c|}
\hline \multirow[b]{3}{*}{ Self-concept } & \multirow{2}{*}{\multicolumn{2}{|c|}{ Rural }} & \multirow{2}{*}{\multicolumn{2}{|c|}{ Urban }} & \multirow{3}{*}{$\begin{array}{c}x^{2} \\
n=600\end{array}$} \\
\hline & & & & & \\
\hline & $\mathrm{F}$ & $\%$ & $\mathrm{~F}$ & $\%$ & \\
\hline Poor & 21 & 7 & 30 & 10 & \\
\hline Average & 81 & 27 & 100 & 33.33 & \\
\hline Good & 198 & 66 & 170 & 56.7 & \\
\hline Total & 300 & 100 & 300 & 100 & $5.71 *$ \\
\hline
\end{tabular}

The table indicated that 66.00 per cent of rural and 56.70 per cent of urban students had high/good self-concept while as 37 per cent and 33.33 per cent of rural/urban students and medium self-concept; whereas, 7 per cent and 10 per cent had poor self-concept. The association between self-concept of rural and urban students were different significantly $(5.71, \mathrm{p}<0.05$ level $)$.

The rural students were having high self-concept than urban. The rural students might be having positive selfconcept, they may be good at decision making, socially acceptable and keep harmonious relationship with the parents, teachers, and friends. This may be the reason for self-concept in rural students than urban students.

Note: p, 0.01evel.

Table 11

Comparison of rural and urban students on self-concept:

\begin{tabular}{|l|rr|r|r|r|}
\hline \multicolumn{7}{|c|}{ Self-concept } \\
\hline \multicolumn{2}{|c|}{ Rural } & & \multicolumn{2}{|c|}{ Urban } & t-vale \\
\hline Mean & SD & Mean & SD & \\
\hline 92.14 & 7.94 & 87.87 & 7.63 & $6.71 * *$ \\
\hline
\end{tabular}

It is study from the above that rural and urban students different significantly on self-concept as the t-value of 6.71 is found to be significant at 1 per cent level. Moreover, the mean scores showed that rural students had better self-concept 92.14 as compared that of urban students87.87 with Standard deviation of 7.94 and 7.63 respectively. 


\section{Comparison of rural and urban students on academic achievement:}

Note: p, 0.01evel.

\begin{tabular}{|c|c|c|c|c|c|}
\hline \multirow[b]{2}{*}{ Socio-economic status } & \multicolumn{2}{|c|}{ Rural } & \multicolumn{2}{|c|}{ Urban } & \multirow{2}{*}{$\begin{array}{c}x^{2} \\
\mathrm{n}=600\end{array}$} \\
\hline & $\mathrm{F}$ & $\%$ & $\mathrm{~F}$ & $\%$ & \\
\hline Low & 255 & 85 & 21 & 7 & \\
\hline Average & 44 & 14.7 & 234 & 78 & \\
\hline Good & 1 & 0.3 & 45 & 15 & \\
\hline Total & 300 & 100 & 300 & 100 & $370.33 * *$ \\
\hline
\end{tabular}

The above table 12 shown that most of the rural students were in the category of low socio-economic status they were 255 in number and with the 85 percentage and 14.7 per cent of rural students had in average category whereas only 1 student in the high category. While as most of the urban students were in the category of average socio-economic status. They were 234 in number and 78 in in percentage. Whereas 15 per cent in high socioeconomic category and 45 in number. While as, only 7 per cent were in the category of low socio-economic category and they were 21 in number. The association between the socio-economic statuses with rural/urban students was found to be significant. As the urban students' family was having better educated parents, occupation and consisted of medium/high income may be the reason for urban students to have better socioeconomic status.

Table 13

Comparison of rural and urban students on Socio-economic status:

Note: $\mathrm{p}, 0.01$ evel.

\begin{tabular}{|l|r|r|}
\hline Rural & Socio-economis status & t-value \\
\hline Mean & 20.47 & \\
\cline { 1 - 1 } & 3.15 & \\
Urban & Socio-economis status & \\
Mean & 29.31 & \\
SD & 4.32 & $28.66^{* *}$ \\
\hline
\end{tabular}

The above table showed that rural and urban students had differed significantly on socio-economic status with tvalue 28.66 at 1per cent level. The observed scores were mean was 20.47 and 29.31 and SD was 3.15 and 4.32 of rural and urban students respectively. It was observed from the mean score that urban students were having higher mean as compared to rural students. Education of parents and their occupation and higher family income might raise the socio-economic status among the urban students when compared to rural students.

Table 14

Distribution of boys and girls on academic achievement:

\begin{tabular}{|c|c|c|c|c|}
\hline & & & \multirow{2}{*}{\multicolumn{2}{|c|}{ Girls $(n=275)$}} \\
\hline \multirow[b]{2}{*}{ Academic achivement } & \multicolumn{2}{|c|}{ Boys $(n=325)$} & & \\
\hline & Frequency & $\%$ & Frequency & $\%$ \\
\hline Excellent & 195 & 60 & 146 & 53.1 \\
\hline Good & 98 & 30.2 & 95 & 34.5 \\
\hline Satisfactors & 21 & 6.5 & 32 & 11.6 \\
\hline Poor & 11 & 3.4 & 2 & 0.7 \\
\hline Total & 325 & 100 & 275 & 100 \\
\hline$x^{2}$ & & $11.51 * *$ & & \\
\hline
\end{tabular}

Note: $\mathrm{p}, 0.01$ evel

The above tabled data showed that 60 per cent of boys and 53.10 per cent of girls were having excellent academic achievement whereas 30.20 per cent of boys and 34.50 per cent of girls and good academic achievement. While 6.5 per cent of boys and 11.60 per cent of girls had satisfactory academic achievements. However, 3.40 per cent of boys and 0.70 per cent of girls had poor academic achievements. The above data also showed that association between levels of academic achievements with boys and girls found to be significant at 1 per cent level. 
Table 15

Comparison of boys and girls on academic achievements:

Note: \#= not significant.

\begin{tabular}{|l|r|r|}
\hline Boys (n-325) & Academic achivements & t-value \\
\hline Mean & 74.941 & \\
\hline SD & 11.913 & \\
\hline Girls (n=275) & Academic achivements & \\
\hline Mean & 73.74 & \\
\hline SD & 11.228 & $1.262 \#$ \\
\hline
\end{tabular}

The above table showed that boys and girls did not differ significantly on academic achievements. The observation of the scores revealed that boys and girls had almost similar academic achievements. The mean scores were 74.941 boys and 73.740 girls with standard deviation 11.913 and 11.228 respectively.

Comparison of t-value of boys and girls on academic achievements was found to be non-significant; it may because of modern and competitive education which provides equal opportunities to the both boys and girls.

Table 16

Comparison of rural and Urban on academic achievements:

\begin{tabular}{|l|r|r|}
\hline Rural & Academic achivements & t-value \\
\hline Mean & 72.37 & \\
\cline { 1 - 1 } & 11.22 & \\
\hline Urban & Academic achivements & \\
\hline Mean & 76.4 & \\
\hline SD & 11.66 & $4.31 * *$ \\
\hline
\end{tabular}

Note: $* * \mathrm{p}<0.01$ level.

The table number 16revels round those rural and urban students differ significantly on academic achievements as $\mathrm{t}$-value ( $\mathrm{t}=4.31 \mathrm{p}<0.01$ level). The mean scores were 72.37 and 76.4 with standard deviation 11.22 and 11.66 respectively.

The table also showed that the comparison of rural/urban students on academic achievements was differed significantly at 1 per cent level. The urban student performance was better compared to rural students. The urban group of students will have highly educated parents, with smart job and smart income. The urban students have also coaching facilities which naturally enhancing and boost the performance in achievements. While as rural students lack such facilities. This might be the reason that rural students did not better in academic achievements.

\section{Conclusion:}

The findings of the study were in the following headings:

Study habits:

There was no association between boys and girls on study habits. Boys and girls did not differ significantly on overall study habits. $8^{\text {th }}, 9^{\text {th }}$ and $10^{\text {th }}$ students differed significantly on study habits. The mean of overall study habits of the $8^{\text {th }}$ standard was higher compared to $9^{\text {th }}$ and $10^{\text {th }}$ students. There was significant association between study habits of girls and academic achievements and there was significant relation between study habits and academic achievements.

The study found significant association between study habits and rural/urban students. They also differed significantly on overall study habits.

\section{Self-concept:}

There was significant association between boys and girls and also did not differ significantly on selfconcept. Mean self-concept of $8^{\text {th }}$ standard students was higher compared to $9^{\text {th }}$ and $10^{\text {th }}$ standard students. There was significant association between self-concept and academic achievements among the boys and girls. There was positive and significant relation between self-concept and academic achievement.

The significant relationship was found between rural and urban students with self-concept. About 50 per cent of rural students had high self-concept while as only 22 per cent urban students had high self-concept. There was significant relationships found between rural/urban student.

\section{Socio-economic status:}

Almost all and equal percentage of boys and girls were found to belong to low and medium socio-economic status, while as meagre amount of percentage of boys and girls belonged to high economic profile/status. 
There was significant association between socio-economic status and academic achievements among the boys and girls.

The study found significant association between socio-economic status and overall development. Rural/urban groups had significant difference on socio-economic status. Urban student was found significantly better socio-economic as compared to rural students.

\section{Academic achievements:}

A number of boys and girls belonged to the category of excellent academic achievements and significant association was found between academic achievements with boys and girls. There was no difference between boys and girls academic achievements. The socio-economic status of the family had significant influence on the academic achievements of the boys and girls.

There was significant difference of boys and girls between rural and urban students with respect to academic achievements.

\section{References:}

[1] A Text Book for B ed. (2014) Basic in Education, ISBN 978-93-5007-283-7, The publication division- NCERT, Campus Sri Aurobindo Marg New Delhi 110016.

[2] http://www.academicjournals.org/IJEAPS

[3] http:// www.yourdictionary.com/study-habits

[4] https://en.wikipedia.org/wiki/Self-concept

[5] Evans Atsiaya siahi \& Julius K. Maiyo (2015) Study of the relationship between study habits and academic achievement of students: A case of Spicer Higher Secondary School, India, International Journal of Educational Administration and Policy Studies Vol. 7(7), pp. 134-141. 